\title{
Geographic Information Office, Information Policy and Services Office
}

The Geographic Information Office, Information Policy and Services Office (IPSO) oversees the bureau's policies and functions related to information services and delivery, i.e., Libraries, Enterprise Web, information centers (through the Natural Science Network), Information Resources Management, and Enterprise Publishing.

For more information about IPSO activities, contact:

$\begin{array}{ll}\text { Hedy Rossmeissl } & \text { Senior Advisor } \\ \text { Donna Burns } & \text { Administrative Assistant }\end{array}$

\section{Library}

The U.S. Geological Survey (USGS) Library is the largest earth sciences collection in the world. This diverse collection provides an information basis for collaborative research supporting the USGS research community.

For more information about the Library activities, contact: Nancy Blair Chief Librarian

Tommie Ann Gard Emily Shen-Torbik Denver Librarian Jenny Prennace Menlo Librarian Flagstaff Librarian

\section{Enterprise Web}

The Enterprise Web is a bureauwide approach to managing USGS information assets on the Web. Through a network of people and resources, the Enterprise Web works with programs and partners to effectively use the USGS Web presence to advance and deliver natural science information. It provides the corporate infrastructure, best practices, and tools to focus the Bureau's Web presence on customer and business needs and to ensure that our Web sites are reliable, secure, and in compliance with all applicable lays, Office of Management and Budget (OMB) requirements, and Department of the Interior (DOI) policy.

For more information about Enterprise Web activities, contact:

Karen Klima

Project Lead

\section{Natural Science Network}

The Natural Science Network (NSN) is a national integrated network of USGS data information and knowledge resources with access from diverse locations that optimizes a user's ability to seek and obtain USGS information and products. The NSN is envisioned to be an organizing framework for the activities of Enterprise Web, Libraries, and information centers. The NSN is currently under development.

For more information about the NSN project, contact:

$$
\text { Mike McDermott Project Lead }
$$

\section{Information Resources Management}

The Information Resources Management (IRM) Team provides bureau-level management of information requirements defined by Public Law, OMB, the National Archives and Records Administration, DOI, and other official sources. These requirements include records management, privacy, Freedom of Information Act (FOIA), Rehabilitation Act, and information technology investment monitoring.

For more information about IRM activities, contact:

$$
\text { Joye Durant (acting) Team Lead }
$$

\section{Enterprise Publishing}

Publishing is an integral part of USGS science and the primary mechanism for transfer of USGS information products to stakeholders. Enterprise Publishing leads the development of bureauwide policies and procedures to facilitate the successful creation and delivery of information products to customers. This effort promotes the use of common publishing business practices and innovative technologies.

For more information about Enterprise Publishing activities, contact:
Greg Allord
Project Lead
Carolyn Reid 